\title{
Pruning effect on Norway spruce (Picea abies (L.) Karst.) growth and quality
}

\author{
Endijs Baders, Janis Donis, Guntars Snepsts, \\ Andis Adamovics and Aris Jansons*
}

\begin{abstract}
Baders, E., Donis, J., Snepsts, G., Adamovics, A., Jansons, A. 2017. Pruning effect on Norway spruce (Picea abies (L.) Karst.) growth and quality. - Forestry Studies | Metsanduslikud Uurimused 66, 33-48. ISSN 1406-9954. Journal homepage: http:// mi.emu.ee/forestry.studies
\end{abstract}

\begin{abstract}
Pruning requires significant investment, therefore, the aim of the study was to characterize occlusion of branch wounds and changes in radial increment as well as frequency of browsing damages after pruning of Norway spruce (Picea abies (L.) Karst.) in order to provide data for financial calculations and recommendations for practical forestry. Altogether 1,614 pruned and 4,368 unpruned trees from 45 Norway spruce stands were measured and cored. Degree of wound occlusion and browsing damages were assessed, and additional volume increment estimated in each stand. Pruning resulted in significant increase of length of branch-free section: for unpruned trees it was $0.3 \pm 0.07 \mathrm{~m}$, but for pruned $3.4 \pm 0.10 \mathrm{~m}$. Branch wounds for most of the trees $(68 \%)$ were filled with resin (occluded), for lower share of trees (31\%) - still open, but for some trees $(1 \%)$ completely occluded. Branch wound occlusion rate was not affected by differences in stand density, but was significantly affected by stand age: proportion of trees with occluded branch scars increased with age. Trees with occluded branch wounds had a significantly higher increase in tree ring width after the pruning in comparison to the period before pruning than trees with open branch wounds, emphasizing the importance of radial increment in development of branch-free layer of wood. Pruning resulted in minor $\left(-7 \%\right.$ or $\left.-0.28 \pm 0.05 \mathrm{~m}^{3} \mathrm{ha}^{-1}\right)$ reduction of annual increment that was statistically significant only up to 3 years after this forest management activity for stands younger than 17 years and with mean height up to $10.5 \mathrm{~m}$. Pruned trees were significantly more browsed than unpruned (6.1\% and $2.7 \%$, respectively).
\end{abstract}

Key words: branch-free wood, branch wound occlusion, radial increment, browsing damages.

Authors' address: Latvian State Forest Research Institute 'Silava', Rigas str. 111, Salaspils, LV-2169, Latvia; *e-mail: aris.jansons@silava.lv

\section{Introduction}

Norway spruce (Picea abies (L.) Karst.) is commercially important wood species in hemiboreal forest zone. According to National forest inventory, Norway spruce is third most common tree species, occupying more than 521 thousand ha of forest land in Latvia (State Forest Service, 2015). Wood of Norway spruce is strong, soft and fine grained, therefore, it is very important raw material for wood industry. A decrease in physical and mechanical properties of the wood due to loose-knots and branchiness (number, size and position) are the most important factors that affects quality of the final wood products (Houllier et al., 1995; Mäkinen et al., 2003) as well determine grade of logs and sawn timber. Both by creating mechanical and visual defects as well as reducing mechanical strength of board due to heterogeneity of wood structure: knots distort wood fibres, causing grain deviation in tangential direc- 
tion (Mattheck \& Kubler, 1995; Hein et al., 2008) and few years after occlusion of stubs fibres forming above the branch collar are curved (Tong et al., 2013).

Branch-free layer of wood is created as a result of self-pruning or artificial pruning. Self-pruning for many tree species is a very slow process even in dense stands. In Norway spruce stands self-pruning first noticeable at age 50 years and more (Mäkinen et al., 2003). Occlusion time of branch scars (the time between the branch death and the moment when the branch scar is completely healed over and is no longer visible on the stem surface) for Norway spruce, Douglas fir (Pseudotsuga menziesii (Mirb.) Franco) can take up to 30-90 years if branches are self-pruned (Paterson, 1938; Petruncio et al., 1997; Mäkinen, 1999; Mäkinen et al., 2003).

Artificial pruning of branches results in smaller diameter of the knots and increase area with knot free lumber. Pruning of growing trees (both coniferous and deciduous) has been carried out in many countries, mainly in the Western Europe, already in the beginning of previous century. Influence of pruning time (season), age of the tree when pruning is carried out, tools and height (or proportion of green crown pruned) on the result (including proportion of branch-free wood, financial evaluation) has been investigated for a number of tree species, including Scots pine (Pinus sylvestris L.) (Romell, 1937; Bergström et al., 2004), loblolly pine (Pinus taeda L.) (Amateis \& Burkhart, 2011), birch Betula spp. (Heiskanen, 1959; Heräjärvi, 2002), hybrid aspen (Populus tremula L. $\times$ P. tremuloides Michx.) (Rytter \& Jansson, 2009), Norway spruce (Metzler, 1996, 1997; Mäkinen et al., 2003).

However, information on the influence of pruning on increment of tree is scarce. Pruning of deadwood does not influence tree growth while the pruning of living tissue can change disrupt and destroy many interrelated processes of tree functionality (Coder, 1998). Stem growth is tightly connected with crown development and structure (Hein et al., 2008). According to physiological processes of tree it is possible that removal of lower branches might free up resources thereby enhance available resources for greater stem growth (Pinkard \& Beadle, 2000). Pruning too severely may reduce growth, due to pruning is taking off more than 25 to $40 \%$ of the live crown length in result of reduced carbon uptake (O'Hara, 1991; Pinkard \& Beadle, 2000).

Rate of changes in radial increment of a tree after pruning is not associated only with the loss of portion of green crown, but is also affected by site environmental conditions (decreasing moisture content due to increased light and surface wind speed); it has been observed, that the influence of pruning differs depending on growing conditions (Metzler et al., 2012). Pruning affects diameter growth more than height growth and removal a few lowest living whorls of branches can even increase the growth of a tree (Schatz et al., 2008).

Previous studies that has been addressed to the occlusion of branch wound after pruning (Metzler, 1996; Petruncio et al., 1997; O'Hara, 2007) presented that removal live branches more frequently occluded. In Latvia interest in prunning had been increasing during last decade, focusing mainly on effect of this forest management operation on growth and wood quality of birch stands. So far has been no experience about effect of pruning on the increment on wound occlusion of Norway spruce. Krigul (1961) concluded that wounds after the removal of dead branches cicatrized in spruce by $30-40 \%$ slower than wounds after live branches were pruned and figures on cumulative (over time) influence on stand productivity are specified seldom.

However, knowledge on both of these factors (changes in increment and branch wound occlusion time) is crucial for financial calculations (Fight et al., 1993), determining the rate of formation of branch-free wood layer. Higher price of branch-free wood represents additional income for forest owner, justifying the investment 
in pruning, as it is e.g. for Scots pine and birch (Víquez \& Pérez, 2005; Ikonen et al., 2009) where there is an existing market for branch-free wood (Macdonald \& Hubert, 2001). In contrast, the branch-free wood of Norway spruce at present has relatively small demand and consequential the price differentiation according to the timber quality has been negligible for Norway spruce price (Phillips, 2004). To facilitate the enhancement of wood quality, in some countries, for example in the United Kingdom, governmental support schemes exist for pruning with a target to increase availability of such wood. That, in turn, could attract industry to develop use of it in specific products, creating a demand (Meyers, 1995; Macdonald \& Hubert, 2001; Phillips, 2004; Pruning Your Forest Trees, 2006).

Furthermore, potential benefits of pruning can be significantly reduced by increased frequency of damages. Most significant of them fungal infection that can enter the tree not only through the branchscar, but also through the browsing damages (Gill et al., 2000; Jactel et al., 2011). A number of wood decay fungi (mainly from Basidiomycete, such as Stereum sanguinolentum, Sistotrema brinkmanii) have been frequently detected in the scars of spruces. Also fungi are frequent colonizers causing wood discoloration, such as Ophiostoma piceae, Nectria fuckeliana and Penicillium spp. (Christiansen et al., 1999; Jactel et al., 2011; Metzler et al., 2012).

Therefore, it is important to assess the changes of damages due to pruning. Additionally, to understand factors that influence growth and development of Norway spruce stands after pruning treatment as well to develop basis for economic calculations and recommendations for implementation of pruning, the aim of our study was to characterize occlusion of branch wounds and changes in radial increment as well as frequency of browsing damages after the pruning of Norway spruce. We hypothesized that pruned trees with healed branch wounds have higher rate with browsing damages than pruned trees with unhealed or "holes" in branch wound.

\section{Material and Methods}

The experiment was established in forests owned by the JSC "Latvia`s State Forests". Pruned Norway spruce stands were chosen randomly from different regions of Latvia, from groups defined by age and pruning time (year): until 2005, 2006 to 2008 and 2009 to 2011 (Figure 1).

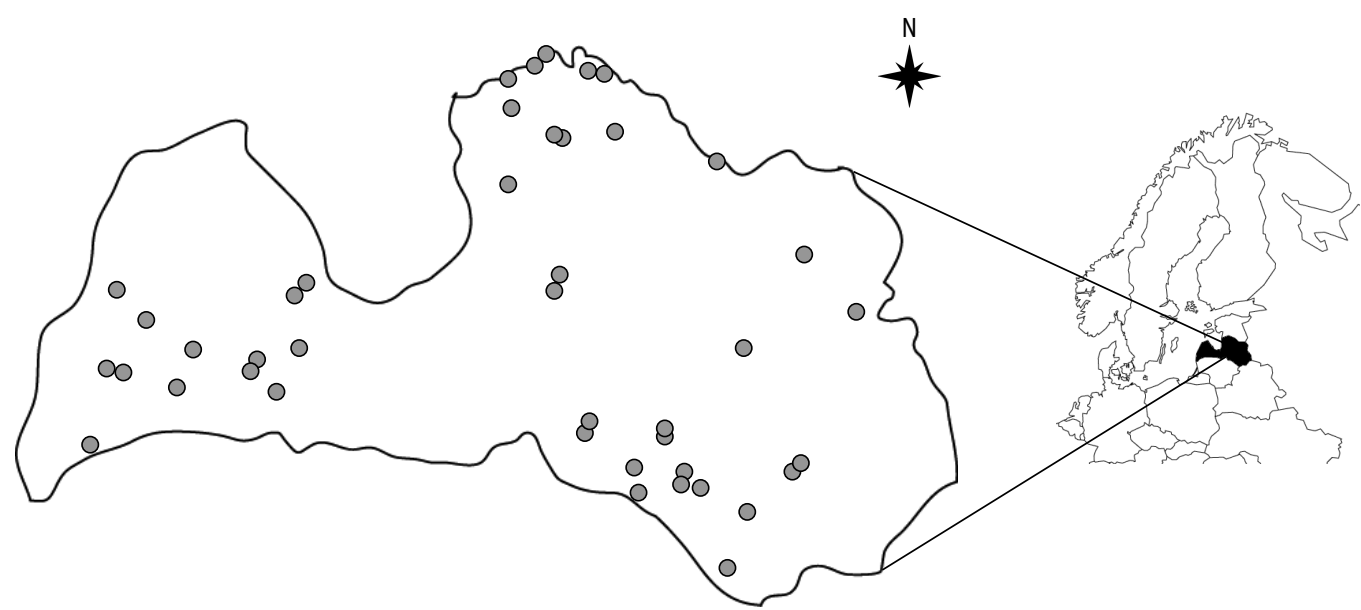

Figure 1. Location of studied spruce stands in Latvia. 
Sampling was carried out from March to May 2012, in 45 stands, that were not smaller than 0.5 ha in the highest site indexes (bonitate) (Figure 2).

All selected stands were spruce dominated (at least $90 \%$ of all trees), but most of them had a natural admixture of birch or other deciduous species. Most of the chosen stands $(60 \%)$ were growing on dry forest types (Oxalidosa $(60 \%)$ and Hylocomiosa $(21 \%))$, other soil conditions (Mercurialiosa mel., Myrtillosa mel., Aegopodiosa, Oxalidosa turf. mel., Myrtillosa turf. mel., Myrtilloso-polytrichosa forest types) were represented by 2 to $6 \%$ of all stands. Age of selected stands ranged from 10 to 28 years (based on the increment core data at breast height). Recent (within the last decade) thinning was carried out in 11 of selected stands. Protection measures, (light bark injury creating resin stripes on stem surface) against browsing damages carried out in sub-set of 11 stands.

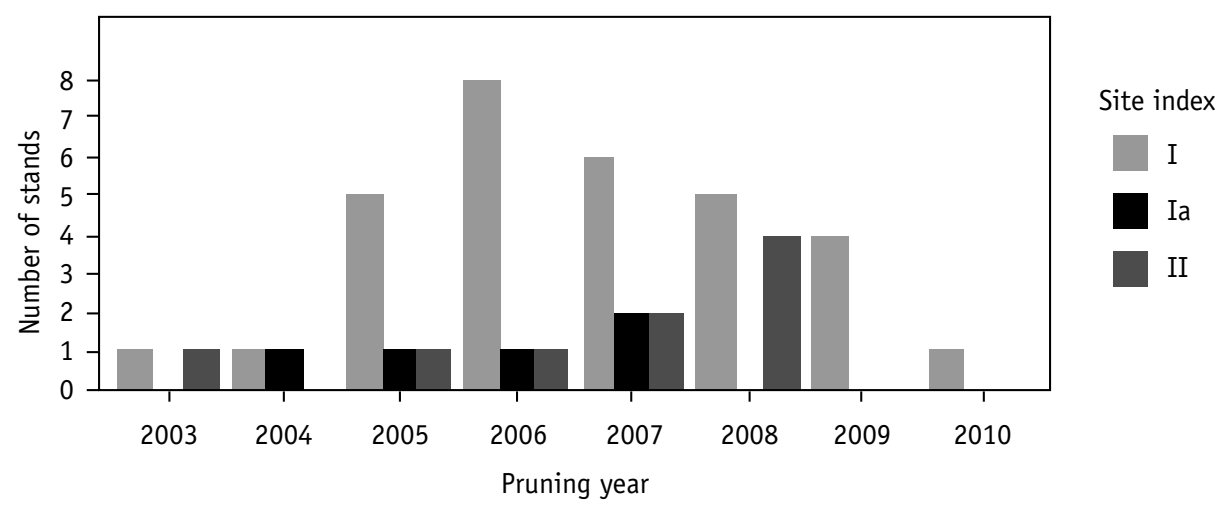

Figure 2. Distribution of stands by pruning year.
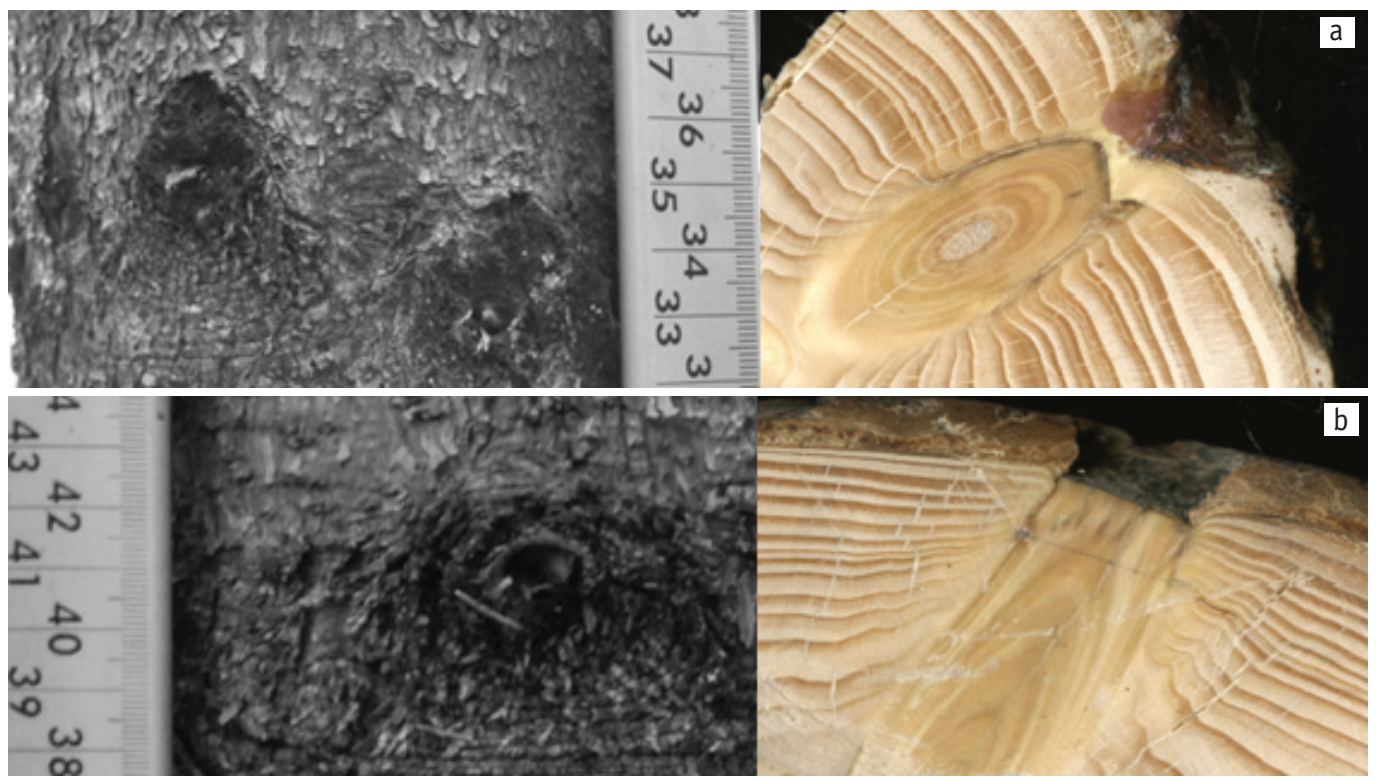

Figure 3. Degree of wound occlusion (healed over and covered with resins (a), open wound or "hole" (b). 
A grid was superimposed over each stand so that 30 grid intersections occurred within stand. At each grid intersection nearest pruned Norway spruce and four its closest neighbouring trees independently of species with a breast height diameter of at least $25 \mathrm{~mm}$ was identified (based on the method of nearest neighbours - Tomppo (1996)). For each tree height and breast height diameter $(d b h)$ were measured. Average tree height and $d b h$ for selected stands were $13 \mathrm{~m}$ and $14 \mathrm{~cm}$, respectively.

Trees were classified into five classes according to the Kraft (1884) where class I is possess by stands dominated trees and class II corresponds to ordinary trees, having relatively well developed crowns. First two classes usually making up the main part of the stand. Classes III to $\mathrm{V}$ include trees of various degree of suppression. Status of the majority of branch scars, describing degree of wound occlusion, was assessed for measured trees in the first $3 \mathrm{~m}$ from stem base in 3 grades: a) completely healed over; b) healed over - branch scars covered with resins (Figure 3a); c) open wound or "hole" (Figure 3b).

Wood samples (increment cores) were taken by Pressler's borer at $1.3 \mathrm{~m}$ height from a root collar from the central tree of each plot and two its closest unpruned neighbours; in total 3803 increment cores were processed. Tree-ring measurement system (LINTAB-IV) and a set of programs (TSAP-Win ${ }^{\text {TM }}$ Scientific) were used (Rinn, 1996) to measure width of tree-rings with an accuracy of $\pm 0.01 \mathrm{~mm}$.

Since only the year of pruning, but not the exact date of it (before or after the formation of annual ring) was known, time periods after pruning were referred to as: 1-2 years, 2-3 years, etc., rather than 1 year, 2 years, 3 years, etc. in calculations of changes in increment.

Data were used to calculate additional cumulative volume increment $\left(Z^{k p}, \mathrm{~m}^{3} \mathrm{~h}^{-1}\right)$ as a result of pruning in each compartment, comparing pruned trees with the unpruned using the method described by
Liepa (1996) (this method has been used recently by Liepa \& Zalkalns (2014):

$Z_{M}^{k p}=12732.4 \psi\left(G H^{\alpha} D^{\beta l g H \mp \varphi-2}-G_{t} H_{t}^{\alpha} D_{t}^{\beta l g H \mp \varphi-2}\right)$,

where $\psi, \alpha, \beta, \varphi$ - empirical coefficients for the Norway spruce $\left(\psi=2.3106 \cdot 10^{-4}, \alpha=\right.$ $0.78193, \beta=0.34175, \varphi=1.18811)$;

$t$ - rating interval of the environmental impact, years;

$G, G_{t}$ - stands basal area at breast height and it is predictive value at the end of the period $t, \mathrm{~m}^{2} \mathrm{ha}^{-1}$ :

$G_{t}=\frac{D_{t}^{2} G}{D^{2}}$,

$D, D_{t}$ - stands mean diameter over the bark and its predictive value of tree at breast height at the end of the period $t, \mathrm{~cm}$ :

$D_{t}=D-0,1 Z_{D}^{k p}$

where $Z_{D}^{k p}$ - additional cumulative increment of stands mean diameter, $\mathrm{cm}$ :

$Z_{D}^{k p}=2 u\left(\sum_{j}^{t} i_{j}+\sum_{j}^{t} i_{j}^{\prime}\right)$

where $u$ - coefficient of the thickness of bark (for the Norway spruce $u=1.046$ ));

$i_{j}$ - the mean value of annual tree ring width for all evaluated trees of the stand under the rating in the time period tmm; $t^{\prime}$ - the interval of retrospection, years;

$i_{j}^{\prime}$ - adjusted annual tree ring width of the evaluated tree to be rated in the interval $t$, $\mathrm{mm}$.

Correction equation:

$i_{j}^{\prime}=\eta i_{k ; j}^{\prime} \wedge \rho$,

where $\eta, \rho$ - calculated connection coefficients $(\eta=0.938$ and $\rho=0.957)$;

$i_{k}$ - the mean values of annual tree ring width of the control trees in the interval $t$, mm (Liepa, 1996).

$H, H_{t}$ - stands' mean height it's predicted value at the end of the time period $t, m$ : 


$$
H_{t}=\mathrm{H}-\mathrm{Z}_{H}^{k p}
$$

where $Z_{H}^{k p}$ - additional cumulative increment of height, at the end of the time period, $\mathrm{m}$ :

$Z_{H}^{k p}=\frac{H Z_{D}^{k p}(a D+b)}{u(c D+100)}$,

where $a, b, c, u$ - empirical coefficients for increment calculations for the Norway spruce $(\mathrm{a}=-0.0256, \mathrm{~b}=1.693, \mathrm{c}=5.794$, $\mathrm{u}=1.046$ (Liepa, 1996)).

Additional cumulative volume increment of the wood yield together with the bark. The value of this index without the bark, $\mathrm{m}^{3} \mathrm{ha}^{-1}$ :

$Z_{M ; b m}^{k p}=\frac{Z_{M}^{k p}}{S}$

where $s$ - coefficients of bark volume:

$$
s=\frac{p D+q}{w D+100}
$$

where $p, q, w$ - empirical coefficients for bark volume for the Norway spruce $(p=$ 5.25, $q=117.6, w=5.0)($ Liepa, 1996)).

Additional annual volume increment of the wood yield after pruning is calculated as the cumulative increment differences of the contiguous years (Liepa, 1996).

$Z_{M}^{p}=M_{A}-m_{A-n}$,

where $Z_{M}^{p}$ - current periodic volume actual increment;

$M_{A}$ - yield of the stand at the age $A, \mathrm{~m}^{3} \mathrm{ha}^{-1}$; $m_{A-n}$ - yield of stand at the age $A-n$, in the end of the interval $n \mathrm{~m}^{3} \mathrm{ha}^{-1}$ (Liepa, 1996).

$Z_{M}^{v p}=1.2732 .4 \psi H^{\alpha} D^{\beta l g H-\varphi-2}\left(\frac{Z_{H}(\alpha+\beta l g D)}{H}+\frac{Z_{d}(\varphi+\beta l g H)}{10 D}\right)$,

where $Z_{M}^{v p}$ - mean current periodical actual volume increment, $\mathrm{m}^{3} \mathrm{ha}^{-1}$;
$H$ - mean height of stand, $\mathrm{m}$;

$D$ - mean diameter of stand at breast height (with bark), cm;

$\mathrm{Z}_{\mathrm{H}}$ - actual increment of mean height, $\mathrm{m}$ :

$$
Z_{H}=\frac{2 i H(a D+b)}{c D+100}
$$

where $i$ - the mean value of annual tree ring width, $\mathrm{mm}$;

$a, b, c$-depending on tree species empirical coefficients for increment calculations.

$\mathrm{Z}_{d}$ - actual increment of mean diameter, $\mathrm{mm}$ :

$Z_{d}=2 i u$

where $u$ - depending on tree species empirical coefficients for increment calculations (Liepa, 1996).

Number of trees per hectare in each stand calculated as arithmetic mean of the quantity of trees in the plots of the stand, which is defined using equation:

$N=\frac{10000}{L^{2} K^{2}}$,

where $N$ - number of trees per hectare;

$L$ - distance from the centre to the third nearest tree + half of the centre tree diameter, m;

$K$ - correction coefficient:

$$
\begin{aligned}
\mathrm{K}= & 0.0034 \mathrm{~L} 3-0.0184 \mathrm{~L} 2- \\
& -0.0456 \mathrm{~L}+1.2173(\mathrm{Liepa}, 1996) .
\end{aligned}
$$

To assess if there are any differences in additional volume cumulative increment depending on the age of the stand, all stands were divided in three groups depending on their age at the pruning year (at $d b h$ $1.3 \mathrm{~m}$ ): 7 to 12 years (14 stands) referred to as "10-year old", 13 to 17 years (22 stands) "15-year old" and 18 to 24 years (8 stands) "20-year old". To assess the significance of the tree height at the age of pruning all stands were divided in 4 groups: 4.5 to $7.5 \mathrm{~m}$ (3 stands) formed the group "6-metres", 7.6 to $10.5 \mathrm{~m}$ (17 stands) - "9-metres", 10.6 to 13.5 m (17 stands) - "12-metres", 
13.6 to $16.5 \mathrm{~m}$ (7 stands) - "15-metres". Lowest trees (6 $\mathrm{m}$ group) were not used in analysis due to low number of stands.

Statistical significance of the differences for annual ring width and proportion of trees with browsing damages between pruned and unaffected spruces was assessed by analysis of variance (ANOVA). Depending on degree of branch wound occlusion, we used ANOVA to detect variation in rate of browsing damage. The Tukey test was used for the multiple comparisons of the mean parameters of stands.

Poisson regression analysis was used to determine whether the density of population of ungulates has an impact on proportion of trees with browsing damages. Regional figures of population densities of red deer (Cervus elaphus L.) and moose (Alces alces L.) in Latvia were taken from the official census data of The State Forest Service for year 2012. All statistical analyses were performed using R 2.13.0 (R Development Core Team, 2011).

\section{Results}

Altogether 5982 trees were measured, including 4368 unpruned and 1614 pruned. Most common degree of wound occlusion was "healed over with resins" (1097 trees) while almost twice less trees had open branch wounds (497) and just in a few cases (20) branch scars were completely healed over. Therefore, only two groups of branch wound occlusion, further in text referred to as "open" (open branch wounds or "holes") and "occluded" (healed over with resins) were analysed. Trees with open branch wounds had a slightly, but not significantly, larger $d b h(1.3 \mathrm{~m})$ than trees with occluded: $159 \pm 3.54 \mathrm{~mm}( \pm \mathrm{SE})$ and $155 \pm 3.18 \mathrm{~mm}$, respectively. Pruned trees were significantly thicker than unpruned (average $d b h=138 \pm 3.52 \mathrm{~mm}$ ). Similar differences were observed for the tree height: non-significant $(p>0.05)$ between trees with open $(14.0 \pm 0.34 \mathrm{~m})$ and occluded
(13.3 $\pm 0.34 \mathrm{~m})$ branch wounds, but significant between pruned $(13.4 \pm 0.33 \mathrm{~m})$ and unpruned $(12.3 \pm 0.35 \mathrm{~m})$ trees. Height to the first dry branch was $3.42 \pm 0.11 \mathrm{~m}$ for trees with open wounds and $3.39 \pm 0.10 \mathrm{~m}$ for trees with occluded $(p>0.05)$; height to the first green branch was $5.25 \pm 0.26 \mathrm{~m}$ and $4.38 \pm 0.23 \mathrm{~m}(p<0.05)$, respectively. On average height to the first dry branch for unpruned trees was notably and statistically significantly lower than for pruned: only $0.26 \pm 0.07 \mathrm{~m}$, differences were not that pronounced, but statistically significant also for the height of the first green branch (4.01 $\pm 0.31 \mathrm{~m}$ for unpruned trees).

Most of pruned trees (80\%) belonged to the I and II Kraft biosocial classes. Almost $68 \%$ of trees in these two classes were with occlude branch wounds, while $30 \%$ with open. Average tree amount with open branch wounds were $11.5 \pm 3.12$ trees per stand, while with resins in branch wounds were $22.8 \pm 3.14$ trees per stand.

Stand density was not statistically significantly different between compartments where the most of the branch wounds of trees were occluded and compartments with open branch wounds: 1376 tree ha ${ }^{-1}$ and 1423 trees ha- ${ }^{-1}$, respectively.

Stand age was a significant factor (chisquare test, $p<0.001$ ) affecting the degree of branch occlusion of branch scars for pruned trees (Figure 4): proportion of trees with occluded branch scars increased with stand age (independently from time after pruning).

\section{Changes of increment}

Additional annual volume increment of the wood yield after pruning (ZipM) was on average $-0.28 \pm 0.05 \mathrm{~m}^{3} \mathrm{ha}^{-1}$ and it was significantly less than zero at the time period $1-2$ years $\left(-0.46 \pm 0.10 \mathrm{~m}^{3} \mathrm{ha}^{-1}\right)$ and $2-3$ years $\left(-0.38 \pm 0.09 \mathrm{~m}^{3} \mathrm{ha}^{-1}\right)$ after pruning (Figure 5).

From 1-2 years till 5-6 years after pruning mean additional cumulative volume increment $(\mathrm{ZkpM})$ changed from $-0.46 \pm$ $0.10 \mathrm{~m}^{3} \mathrm{ha}^{-1}$ to $-1.38 \pm 0.69 \mathrm{~m}^{3} \mathrm{ha}^{-1}$ and estimated values were significantly $(p<0.05)$ less than zero, but did not differ mutually. 


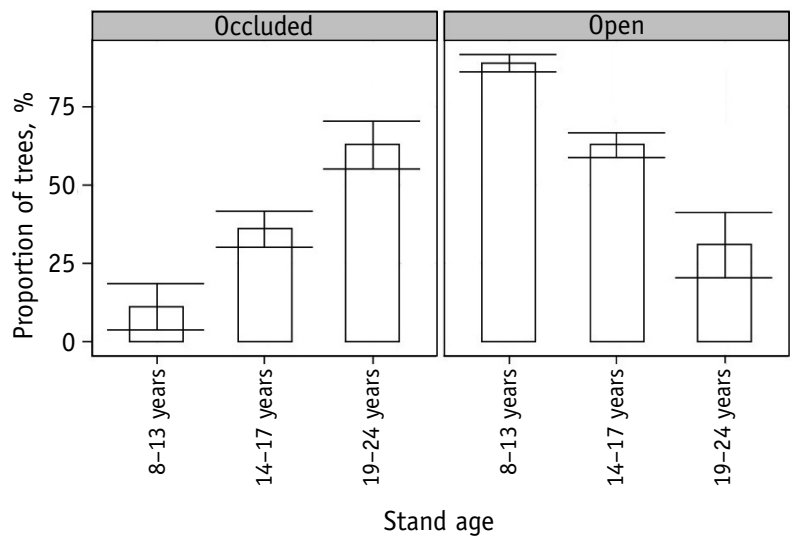

Figure 4. Percentage of trees with a different degree of branch wound occlusion depending of stand age, \% (error bars represent $95 \%$ confidence interval for mean).
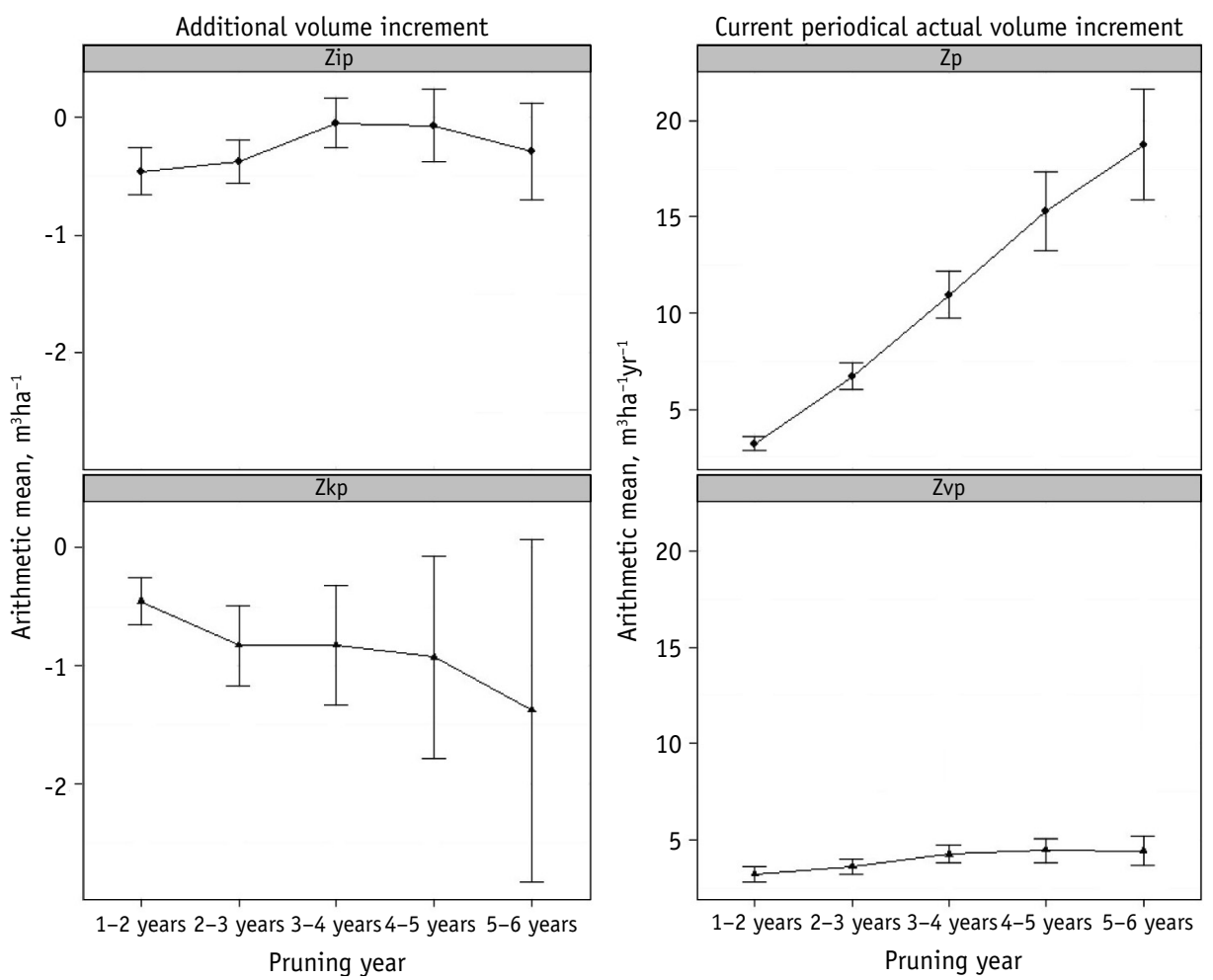

Figure 5. Additional volume increment $\left(\mathrm{m}^{3} \mathrm{ha} \mathrm{a}^{-1}\right)$ and current periodical actual volume increment $\left(\mathrm{m}^{3} \mathrm{ha}^{-1}\right.$ year $^{-1}$ ) depending of the time period after pruning (values are given as mean $\pm \mathrm{SE}$ ): ${ }^{1} \mathrm{ZipM}$ - annual additional volume increment; ${ }^{2} \mathrm{ZkpM}$ - additional cumulative volume increment; ${ }^{3} \mathrm{ZpM}$ - current periodical actual volume increment; ${ }^{4} \mathrm{ZvpM}$ - mean current periodical actual volume increment.

Current periodic volume actual increment $(Z p M)$ was statistically significantly influenced by the time after pruning until the period 4-5 years after this forest manage- ment activity: $Z p M$ values were increasing from $3.21 \pm 0.19 \mathrm{~m}^{3} \mathrm{ha}^{-1}$ year $^{-1}$ in 1-2 years after pruning to $18.75 \pm 1.38 \mathrm{~m}^{3} \mathrm{ha}^{-1}$ year $^{-1}$ in 5-6 years after pruning. Mean current peri- 
odical actual volume increment (ZvpM) was not significantly affected by the time after pruning and ZvpM values ranged between $3.21 \pm 0.37 \mathrm{~m}^{3} \mathrm{ha}^{-1}$ at the time period 1-2 years after pruning to $4.45 \pm 0.31 \mathrm{~m}^{3} \mathrm{ha}^{-1}$ at the time period $4-5$ years (Figure 5 ).

Mean additional cumulative annual volume increment and also mean additional annual volume increment in the time period up to 6 years were negative in 10 and 15 year old stands. In these age groups mean additional cumulative annual volume increment was significantly less than zero $(p<0.05)$ in the time period up to 5 years after pruning operation, but mean additional annual volume increment in the time period up to 2 years after pruning was significantly less than zero $(p<0.05)$. For the group 20 -year stands both of these types of additional volume in different time periods after pruning were not significantly different from zero (Figure 6).

In the height group 9-metres both calculated additional volume increments were negative; $Z k p M$ in all time periods and ZipM in period 1-2 years were significantly less than zero. In height group 12 and 15 metres similar trend in changes of the increment depending on the time after pruning were observed, but none of the additional increments was significantly different from zero (Figure 7). a)
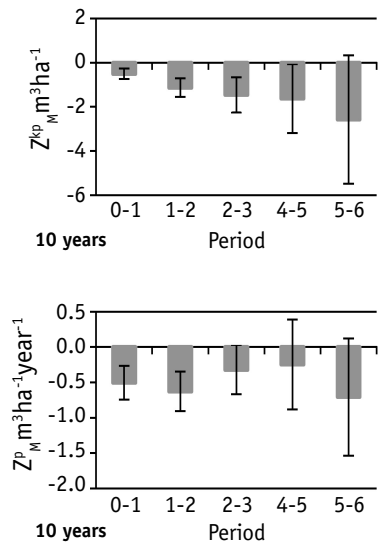
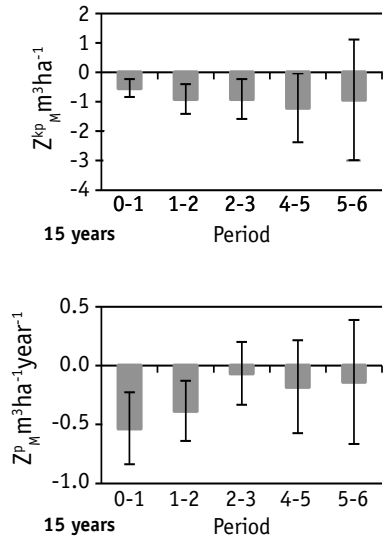
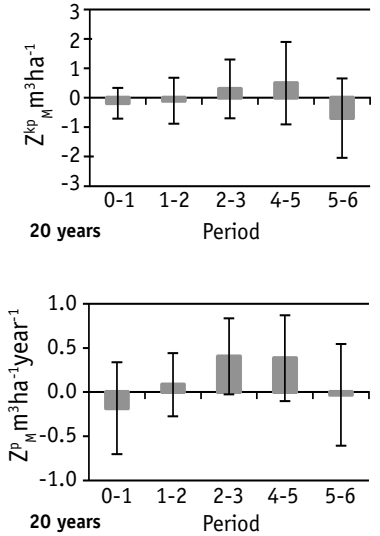

Figure 6. Mean additional annual volume cumulative increment, $\mathrm{m}^{3} \mathrm{ha}^{-1}(\mathrm{a})$ and mean additional annual volume increment, $\mathrm{m}^{3} \mathrm{ha}^{-1}$ year-1 (b) depending on the stand age at the pruning year and the length of time after pruning (values are given as mean $\pm \mathrm{SE}$ ).

a)

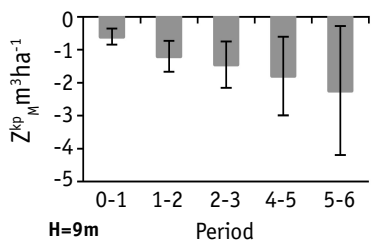

b)

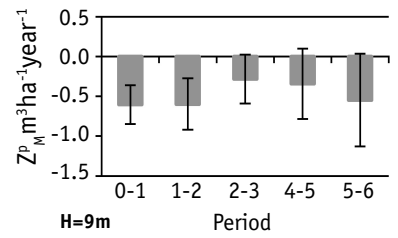

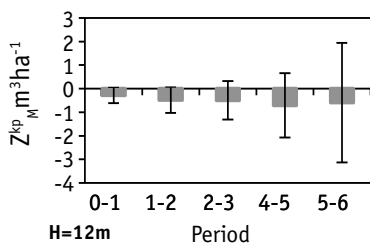

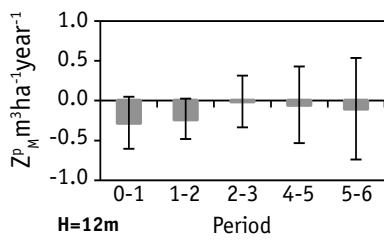

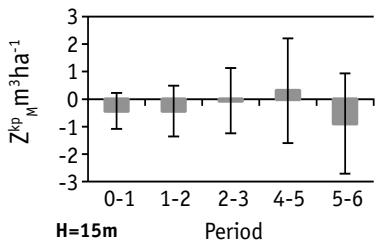

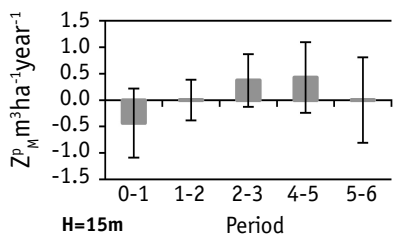

Figure 7. Mean additional cumulative annual volume increment, $\mathrm{m}^{3} \mathrm{ha}^{-1}(\mathrm{a})$ and mean additional annual volume increment, $\mathrm{m}^{3} \mathrm{ha}^{-1}$ year $^{-1}$ (b) depending on the height category at the pruning year and the length of time after pruning (values are given as mean $\pm \mathrm{SE}$ ). 


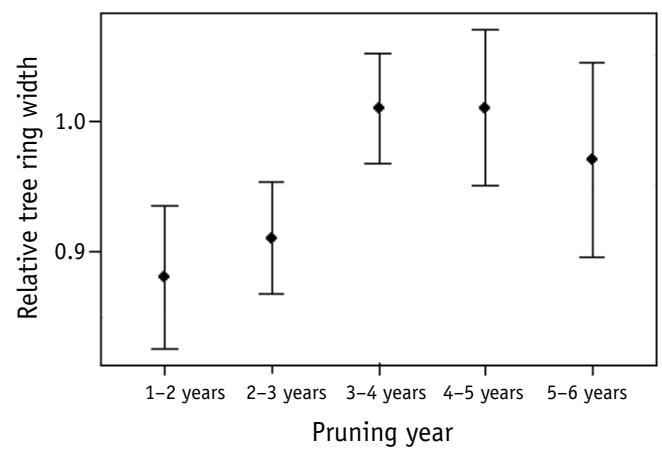

Figure 8. The relative tree rings width (imeasured/ iexpected) depending of time period after pruning (values are given as mean $\pm \mathrm{SE}$ ).
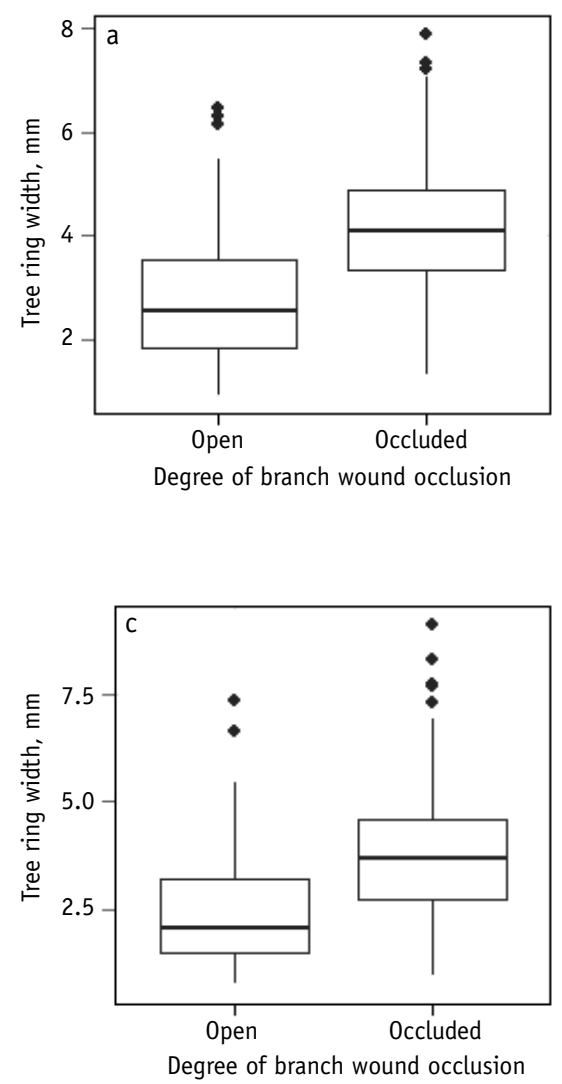

Relative tree ring width $\left(i_{\text {measured }} / i_{\text {expected }}\right)$ in the time periods $1-2$ years and 2-3 years after pruning was $0.88 \pm 0.03$ and $0.91 \pm$ 0.02 (statistically significantly lower than expected), but in the time periods up to 5-6 years' radial increment did not differ significantly $(p>0.05)$ from the expected values (Figure 8).

For trees from the first two Kraft classes, pruned in year 2006 (largest number of stands), revealed that average tree ring width for 12 year period (6 years before pruning and 6 years after) was smaller for trees with open branch scares $(0.28 \pm 0.15 \mathrm{~mm})$
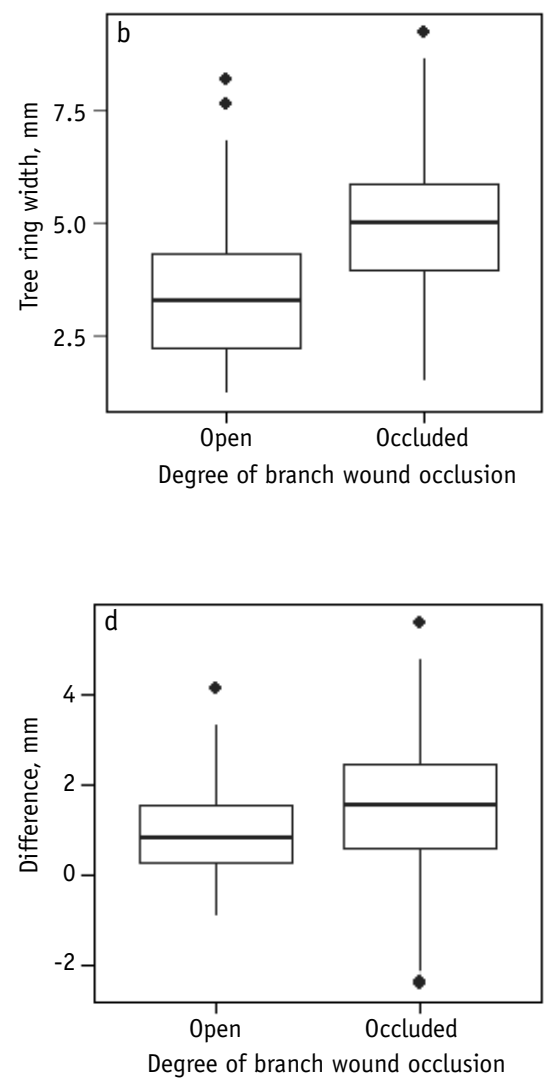

Figure 9. Average tree ring width depending on the degree of branch wound occlusion; average of the tree ring width for 12 year period (six years before pruning year and six years after) (a); average of the tree rings width five years before pruning year (b); average of the tree rings width five years after pruning year (c); the difference between average of the three-tree rings' width before pruning year and average of tree rings' width four to six years after pruning (d). 


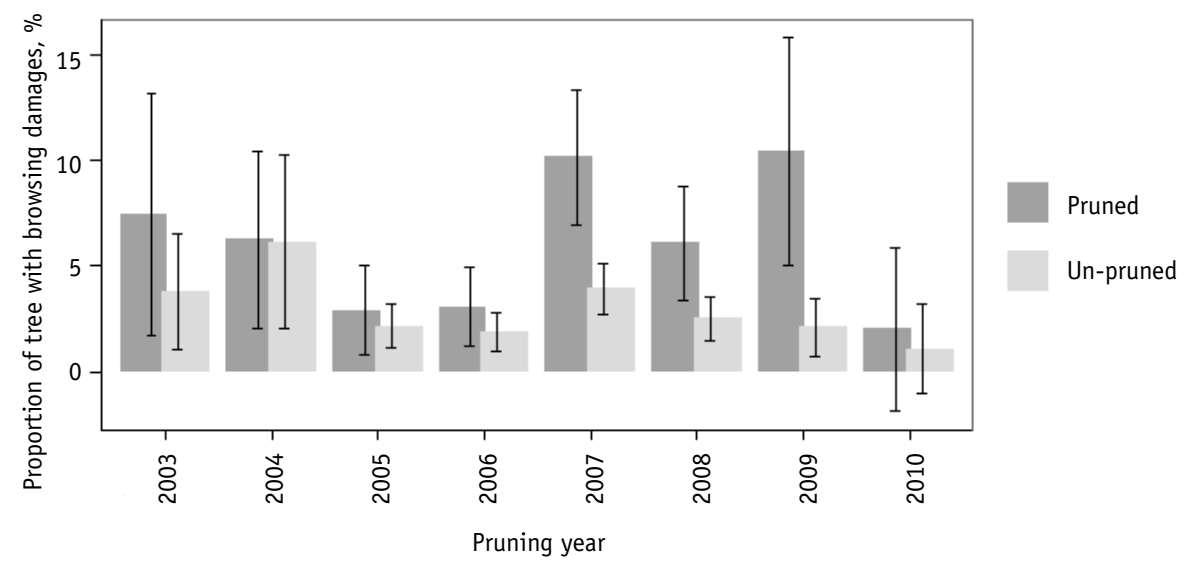

Figure 10. Browsing damages in pruned and un-pruned spruce stands in relation to the pruning year (error bars represent $95 \%$ confidence interval for mean).

than for trees with occluded (0.41 \pm $0.10 \mathrm{~mm}$ ) (Figure 9a), differences were statically significant $(p<0.001)$.

Difference of mean ring-width between these two groups of trees was significant $(p<0.001)$ both before and after the pruning (Figure 9b, 9c), but trees with occluded branch scars had statistically significantly $(p<0.001)$ higher increase in annual ring width after the pruning in comparison to the period before pruning $(0.15 \pm 0.12 \mathrm{~mm})$ than trees with open branch scares $(0.98 \pm$ $0.12 \mathrm{~mm}$ ) (Figure 9d).

\section{Browsing damages}

Browsing damages were found for less than $5 \%$ of spruces, but pruned trees were significantly $(p<0.05)$ more affected than unpruned (proportion of trees with damages $6.5 \%$ and $2.9 \%$, respectively). Trees with open branch wounds were more affected than trees with occluded $(10 \%$ and $5 \%$ respectively, $p<0.05)$. Notable variation among stands and years of pruning was observed (Figure 10).

In stands were protection measures was done proved to be efficient and reduced average frequency of browsing damages by half, but there was no significant rela- tionship $(p>0.05)$ between these stands. Density of ungulates, which might cause browsing damages for Norway spruces moose (Alces alces L.) and red deer (Cervus elaphus L.) - differed widely (from 2.7 to 37.4 animals per $1000 \mathrm{ha}$ ) between regions where stands were sampled (Figure 11).

The Poisson regression model did not show significant $(p>0.05)$ relationship between it (Figure 11).

\section{Discussion and Conclusions}

In Finland, pruning also gained increasing interest, and Blomqvist (1879) published a booklet related to pruning in the latter part of the 19th century. According to the German example, he recommended the pruning of Norway spruce, though he had reservations against the pruning of living branches. Based on the Finnish literature, it was, however, believed that fungal infections were common in the pruning wounds on Norway spruce (Grönvall, 1908; Venho, 1915; Lakari, 1920). The incidence was higher in trees pruned in the autumn than in trees pruned in the winter or summer, and infections were more likely to occur in wounds from removed living branches. Although, more positive results were later 
A

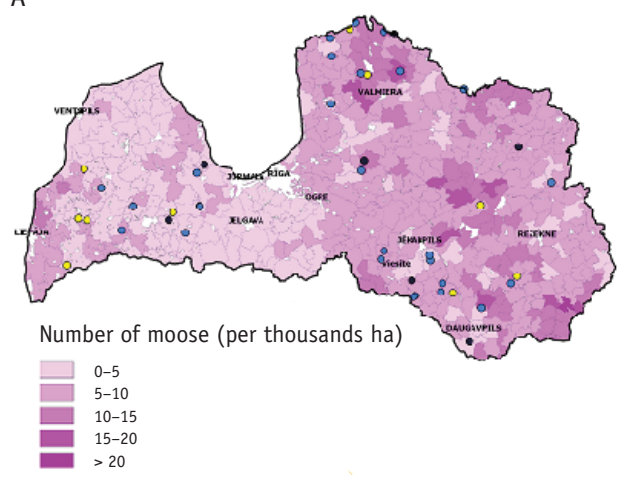

B

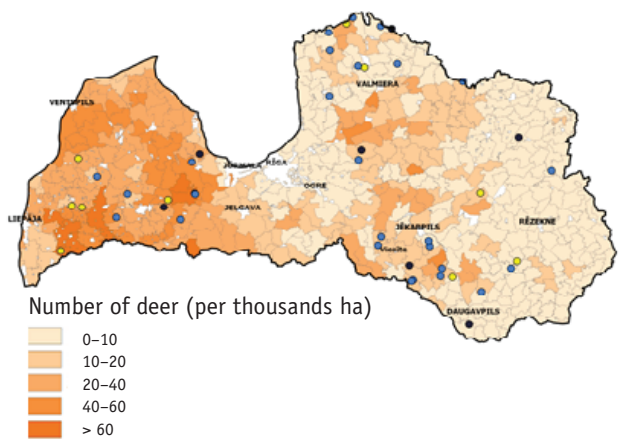

Location of the stands

Damaged trees:

None

- From 1 to 10

More than 11

Figure 11. The density of moose (A) and deer (B) population in 2012 (number of animals per thousand hectares, according to State Forest Service) in the territory of Latvia and location of pruned stands.

achieved (Heikinheimo, 1953), pruning of Norway spruce live knots is still not recommended. In the guidelines for forestry practice, only the pruning of dead branches is currently accepted (Hyvän metsänhoidon suositukset, 2006).

Quality class of sawlogs is to a large extent determined by evenness of log surface and presence of green or dry branches or branch scars (Macdonald \& Hubert, 2001). The way knots are occluded follows a general pattern of grain deviation around branch wounds (Jäppinen, 2000). Time is required for occlusion of branch wounds after pruning.

Our findings coincided with the data from literature that average occlusion time for Norway spruce $2 \mathrm{~cm}$ thick branch wounds is 4-12 years (Paterson, 1938; Metzler, 1997; O'Hara, 2007), on average 5.5 years (Metzler, 1996): major part of the branch wounds in the sampled stands (pruned 3-10 years before assessment) had already occluded. We found that the portion of open branch wounds is higher in younger stands, that could be a result of a slower radial growth or due to the fact that larger and older trees exude larger amount of resin (Schwerdtfeger, 1955), contributing to wound occlusion.

Importance of radial increment in branch wound occlusion was confirmed also by the detailed analysis of the radial increment for stands pruned at year 2006: average annual ring width was larger for trees with occluded branch wounds (in comparison to those with open) both before and after the pruning, but the difference increased starting from fourth year after the pruning. The importance of the radial increment on branch wound occlusion was reported also for birch (Betula pendula Roth.) at the age of 33 years, where positive short-term (one year) influence on radial increment was found after pruning (Schatz et al., 2008). Our results, in contrast, demonstrate reduction of radial increment for Norway spruce after pruning, and the effect is significant $(p<0.05)$ up to 3 years after this silvicultural practice, resulting in reduction of $0.28 \pm 0.05 \mathrm{~m}^{3} \mathrm{ha}^{-1}$ or $-7 \%$ of mean periodic volume increment.

These changes might be attributed to decline of the green crown, since also other 
damages affecting it, are reported to have similar effect on increment. For example, European pine sawfly (Neodiprion sertifer Geoffr.) caused a reduction of $0.34 \mathrm{~m}^{3}$ per $\mathrm{m}^{2}$ of basal area in Scots pine stands (Šmits et al., 2008).

Mean additional cumulative annual volume increment and also mean additional annual volume increment was significantly less than zero in younger stands, but in age group 20 years both were not significantly different from zero. Similarly, we found also that pruning treatments caused a significant reduction of additional volume increment in stands with height up to 10.5 metres and up to 3 years after pruning, but in higher stands reduction of volume increment was insignificant. Both of the findings could be attributed to higher proportion of green crown being affected in pruning of younger, shorter trees, since there were no changes in height of pruning from stand to stand. As a result, younger stands had mostly open branch wounds while older - mostly occluded. Removal of living crown requires adjustment in nutrient allocation for new foliage production or accelerated rates of photosynthesis. Therefore, it has been recommended to restrict maximal portion of green crown to be removed in one pruning occasion, e.g. not more than 33\% (Philips, 2004; O'Hara, 2007) to minimize or avoid reduction of annual increment.

Pruned trees with a thin bark are especially susceptible to bark stripping, whereas enhanced radial growth and the development of a thick bark reduces the attractiveness of stems for deer (Jactel et al., 2011). Bark damages can be caused not only by browsing, but also fraying (rubbing antlers up and down the stem, commonly associated with mating behaviour) and for some tree species (including spruces) the side branches are reported to provide protection against these damages (Gill, 1992). Therefore, it is no surprise that in our study higher proportion of damaged trees were found among the pruned ones. The peak age of susceptibility to bark stripping or fraying damages is between 10 to 38 years which coincides with the pruning target age (Vasiliauskas, 2001; Gill, 2003; Čermak \& Strejček, 2007). Browsing damages for Norway spruce can lead to the development of fungal infections, further reducing timber quality (McLaughlin \& Šica, 1996; Vasiliauskas, 2001; Gill, 2003), therefore should be avoided as much as possible.

Proportion of the damaged trees varied notably between stands, but on average was lower than that reported by Gill (2003): $11.4 \%$. Variation found on our study could be affected by a number of factors: average and local deer population density (e.g. nearby locations of supplemental feeding, done by hunters, are shown to increase risk of browsing damages) as well as availability of alternative feeding sources. Several studies of Scots pine have found that the extent of browsing on young trees is dependent on the density of the moose population (Bergström \& Vikberg, 1992; Hörnberg, 2001).

In contrast, our results did not found a link between population densities of deer or moose and proportion of trees with browsing damages, probably indicating that other (more local) factors, e.g. stand density (Lyly \& Saksa, 1992) other silvicultural treatments (Edenius et al., 2002; Deal et al., 2003), play an important role. Therefore, it was not possible to determine a critical density of ungulates when protection of the pruned trees is essential.

To conclude: pruning has reached its goal - branch-free part of Norway spruce had been increased from $0.3 \pm 0.07 \mathrm{~m}$ to 3.4 $\pm 0.10 \mathrm{~m}$ (roughly the length of one $\log$ ) and branch wounds for most of the trees (68\%) were filled with resin (occluded). Initial hypothesis had been confirmed pruned trees were significantly more browsed than unpruned; however, there were notable variation among sites and mean proportion was not high $-6.1 \%$ and $2.7 \%$, respectively. 
Acknowledgements. This research was conducted as a part of the project "Norway spruce pruning and stem mechanical protection effect on further tree growth and quality". This project was funded by the JSC "Latvia State forests". The authors thank participants of LSFRI "Silava" research group: Rieksts-Riekstinš̌ J. and Purinšs M. for field assistance.

\section{References}

Amateis, R.L., Burkhart, H.E. 2011. Growth of young loblolly pine trees following pruning. - Forest Ecology and Management, 262(12), 2338-2343.

Bergström, B., Gref, R., Ericsson, A. 2004. Effects of pruning on heartwood formation in Scots pine trees. - Journal of Forest Science, 50(1), 11-16.

Bergström, R., Vikberg, M. 1992. Winter browsing on pine and birch in relation to moose population density. - Alces, 1, 127-131.

Blomqvist, A.G. 1879. On growing of trees. (Om uppqvistning af träd). - Finska Forstföreningens Meddelanden, 1, 1-18. (In Swedish).

Čermák, P., Strejček, M. 2007. Stem decay by Stereum sanguinolentum after red deer damage in the Českomoravská vrchovina highlands. - Journal of Forest Science, 53, 567-572.

Christiansen, E., Krokene, P., Berryman, A.A., Franceschi, V.R., Krekling, T., Lieutier, F., Lönnborg, A., Solheim, H. 1999. Mechanical injury and fungal infection induce acquired resistance in Norway spruce. - Tree Physiology, 19, 399-403.

Coder, K.D. 1998. Pruning effects on tree growth: Growth regulation consequences (Tree growth control systems series). Athens, University of Georgia Service of Forest Resources. 3 pp.

Deal, R.L., Barbour, R.J., Mcclellan, M.H., Parry, D.L. 2003. Development of epicormic sprouts in Sitka spruce following thinning and pruning in southeast Alaska. - Forestry, 76(4), 401-412.

Edenius, L., Bergman, M., Ericsson, G., Danell, K. 2002. The role of moose as a disturbance factor in managed boreal forests. - Silva Fennica, 36, 5767.

Fight, R.D., Bolon, N.A., Cahill, J.M. 1993. Financial analysis of pruning Douglas-fir and ponderosa pine in the Pacific Northwest. - Western Journal of Applied Forestry, 8(2), 58-61.

Gill, R.M.A. 1992. A review of damage by mammals in north temperate forests: 1. Deer. - Forestry, 65(2), 145-169.

Gill, R.M.A. 2003. The economic implications of deer damage in woodlands and forests. - The future for deer: The Deer Initiative Conference, 28-29 March 2003. Peterborough, English Nature Research Reports, 548, 26-31.
Gill, R.M.A., Webber, J., Peace, A. 2000. The economic implications of deer damage: a review of current evidence. Final report for The Deer Commission for Scotland. Surrey, Alice Holt Lodge. 49 p.

Grönvall, A. 1908. A little about pruning of Norway spruce. (Vähän näreitten karsimisesta). - Tapio, 1(9), 378-379. (In Finnish).

Heikinheimo, O. 1953 Artificial pruning of trees. (Puiden keinollisesta karsimisesta). - Metsätaloud Aikak, 76(12), 399-402. (In Finnish with English summary).

Hein, S., Weiskittel, A.R., Kohnle, U. 2008. Branch characteristics of widely spaced Douglas-fir in south-western Germany: Comparisons of modelling approaches and geographic regions. - Forest Ecology and Management, 256(5), 1064-1079.

Heiskanen, V. 1959. Studies on pruning of birch. Helsinki. 68 pp.

Heräjärvi, H. 2002. Internal knottiness with respect to sawing patterns in Betula pendula and B. pubescens. Baltic Forestry, 8(1), 42-50.

Hörnberg, S. 2001. Changes in population density of moose (Alces alces) and damage to forests in Sweden. - Forest Ecology and Management, 149, 141-151.

Houllier, F., Leban, J.M., Colin, F. 1995. Linking growth modelling to timber quality assessment for Norway spruce. - Forest Ecology and Management, 74, 91-102.

Hyvän metsänhoidon suositukset. 2006. (Finnish Guidelines for Good Silviculture). Helsinki, Metsätalouden kehittämiskeskus Tapio. 59 pp. (In Finnish).

Ikonen, V.P., Kellomäki, S., Peltola, H. 2009. Sawn timber properties of Scots pine as affected by initial stand density, thinning and pruning: a simulation based approach. - Silva Fennica, 43(3), 411-431.

Jactel, H., Branco, M., Gonzalez-Olabarria, J.R., Grodzki, W., Langstom, B., Moreira, F., Netherer, S., Orazio, C., Piou, D., Santos, H., Schelhaas, M.J., Tojic, K., Vodde, F. 2011. Forest stands management and vulnerability to biotic and abiotic hazards. Technical Report 64. European Forest Institute, Finland. 88 pp.

Jäppinen, A. 2000. Automatic sorting of sawlogs by grade. Summary. PhD Thesis, Uppsala, Acta Universitatis Agriculturae Sueciae. 41 pp.

Kraft, G. 1884. Contributions to the science of thinnings, coupe designs and interventions for light management. (Beiträge zur Lehre von den Durchforstungen, Schlagstellungen und Lichtungshieben). Hannover, Klindworth's Verlag. 147 pp. (In German).

Krigul T. 1961. Pine and spruce stands pruning. (Männi- ja kuusepuistute laasimine). Tartu, Loodusuurijate Selts. 194 pp. (In Estonian).

Lakari, O.J. 1920. Studies on pruning of Norway spruce. (Tutkimuksia kuusen karsimisesta). Communicationes Instituti Forestalis Fenniae, 2, 1-43. (In Finnish with German summary). 
Liepa, I. 1996. Theory of increment. (Pieauguma mācība). Jelgava, LLU. 124 pp. (In Latvian).

Liepa, I., Zalkalns, O. 2014. The Diversity of the environmental impact in Kurzeme. - Journal of Life Science, 8(7), 570-581.

Lyly, O., Saksa, T. 1992. The effect of stand density on moose damage in young Pinus sylvestris stands. Scandinavian Journal of Forest Research, 7, 393-403.

Macdonald, E., Hubert, J. 2001. A review of the effects of silviculture on timber quality of Sitka spruce. Forestry, 75(2), 107-138.

Mäkinen, H. 1999. Growth, suppression, death, and self-pruning of branches of scots pine in southern and central Finland. - Canadian Journal of Forest Research, 29, 585-594.

Mäkinen, H., Ojansuu, R., Sairanen, P., Yli-Kojola, H. 2003. Predicting branch characteristics of Norway spruce (Picea abies (L.) Karst.) from simple stand and tree measurements. - Forestry, 76(5), 525-546.

Mattheck, C., Kubler, H. 1995. Wood: The internal optimization of trees. Berlin, Springer Verlag. 129 pp.

McLaughlin, W., Šica, L. 1996. Bark striping caused by moose and an its related fungal infection. (Alņu radītie mizas plēsumi parastai eglei un ar tiem saistītās trupes izraisitaju infekcijas). Mežzinātne, 39(6), 26-37. (In Latvian).

Metzler, B. 1996. Fungal infection rate and healing process after green pruning in Norway spruce. Forest Planning and Management Tools (EECProject AIR1-CT92-0715). Final Report. Germany, 200-208.

Metzler, B. 1997. Quantitative assessment of fungal colonization in Norway spruce after green pruning. European Journal of Forest Pathology, 27, 1-11.

Metzler, B., Hecht, U., Nill, M., Brüchert, F., Fink, S., Kohnle, U. 2012. Comparing Norway spruce and silver fir regarding impact of bark wounds. - Forest Ecology and Management, 274, 99-107.

Meyers, S.P. 1995. Profit potential from pruning: a look from down under. - The economics of commercial pruning and certification in New Zealand. School of Forestry. Auburn, Auburn University. p 15.

O'Hara, K.L. 1991. A biological justification for pruning in coastal Douglas-fir stands. - Western Journal of Applied Forestry, 6(3), 59-63.

O'Hara, K.L. 2007. Pruning wounds and occlusion: A long-standing conundrum in forestry. - Journal of Forestry, 105(3), 131-138.

Paterson, A. 1938. The occlusion of pruning wounds in Norway spruce (Picea excelsa). - Annals Botany, 2(3), 681-698.

Petruncio, M., Briggs, D., Barbour, R.J. 1997. Predicting pruned branch stub occlusion in young, coastal Douglas-fir. - Canadian Journal of Forest Research, 27(7), 1074-1082.

Philips, H. 2004. Pruning adds value to plantations. [WWW document]. URL http://www.coford.ie/ media/coford/content/publications/ projectreports/cofordconnects/Pruning.pdf [Accessed 1 March 2017].
Pinkard, E.A., Beadle, C.L. 2000. A physiological approach to pruning. - International Forestry Review, 2(4), 295-305.

Pruning Your Forest Trees. 2006. [WWW document]. URL http://www.shelterwoodmaine.com/pdf/ pruning\%20trees.pdf [Accessed 1 March 2017].

R Development Core Team. 2011. R: A language and environment for statistical computing, Vienna, $\mathrm{R}$ Foundation for Statistical Computing ISBN 3-900051-07-0. [WWW document]. - URL http:// www.R-project.org/. [Accessed 21 February 2017].

Rinn, F. 1996. TSAP Reference Manual: computer program for tree ring analysis and presentation. Version 3.0. Heidelberg. 262 pp.

Romell, L.G. 1937. Results of natural and artificial pruning in Scots pine. (Kvistrensning och övervallning hos okvistad och torrkvistad tall). - Journal of Swedish Forest Society, 35, 299-328, (In Swedish with English summary).

Rytter, L., Jansson, G. 2009. Influence of pruning on wood characters in hybrid aspen. - Silva Fennica, 43, 689-698.

Schatz, U., Herajarvi, H., Kannisto, K., Rantatalo, M. 2008. Influence of saw and secateur pruning on stem discolouration, wound cicatrisation and diameter growth of Betula pendula. - Silva Fennica, 42, 295-305.

Schwerdtfeger, F. 1955. Pathogenese der BorkenkiiferEpidemie 1946-1950 in Nordwestdeutschland. (Pathogenesis of bark beetle epidemic 1946-1950 in north-wetern Germany). G. Göttingen, Schriftenreihe der Forstlichen Fakultt der Universität Göttingen. 135 pp. (In German).

Šmits, A., Strike, Z., Liepa, I. 2008. Effect of defoliation caused by European pine sawfly Neodiprion sertifer Geoffr. on Scots pine (Pinus sylvestris L.). (Priežu rūsganās zāğlapsenes (Neodiprion sertifer Geoffr.) izraisītās defoliācijas ietekme uz priežu (Pinus sylvestris L.) pieaugumu). - Mežzinātne, 18(51), 53-73. (In Latvian).

State Forest Service. 2015. State Forest Service, Annual Report 2015. (Valsts Meža Dienests. 2015. Gada pārskats). [WWW document]. - URL https:// www.zm.gov.lv/public/files/CMS_Static_Page_ Doc/00/00/00/84/06/Publiskaisparskats2015. pdf [Accessed 18 July 2017]. (In Latvian).

Tomppo, E. 1996. Multi-source national forest inventory of Finland. - Proceedings of the Subject Group S4.02-00 "Forest Resource Inventory and Monitoring" and Subject Group S4.12-00 Remote Sensing Technology, Joensuu, Finland, 1996. - European Forestry Institute Proceedings, 7, 27-41.

Tong, Q., Duchesne, I., Belley D., Beaudoin, M., Swift, E. 2013. Characterization of knots in plantation white spruce. - Wood and Fiber Science, 45(1), 1-14.

Vasiliauskas, R. 2001. Damage to trees due to forestry operations and its pathological significance in temperate forests: a literature review. - Forestry, 74(4), 319-336. 
Venho, B. 1915. Observations on decay defects caused by pruning in Norway spruce. (Havaintoja karsimisen aiheuttamista lahovioista kuusessa). Metsätaloud Aikak, 2(11), 332-339. (In Finnish).
Víquez, E., Pérez, D. 2005. Effect of pruning on tree growth, yield, and wood properties of Tectona grandis plantations in Costa Rica. - Silva Fennica, 39(3), 381-390.

Received March 2, 2017, revised April 28, 2017, accepted May 15, 2017 